\title{
İlkokul Matematik Ders Kitaplarında Bulunan Ünite Değerlendirme Sorularının Yenilenmiş Bloom Taksonomisine Göre İncelenmesi*
}

\author{
Evaluation of Unit Evaluation Questions in Primary School \\ Mathematics Course Books according to the Revised Bloom's \\ Taxonomy
}

\author{
Lütfi ÜREDİ**, Hakan ULUM***
}

\begin{abstract}
Öz: Bu araştırmanın amacı ilkokullarda okutulan 1,2,3 ve 4. sınıf matematik ders ve çalışma kitaplarındaki ünite değerlendirme sorularını, Yenilenmiş Bloom Taksonomisi'nden yararlanarak analiz etmek, ünite değerlendirme sorularının üst düzey bilişsel becerileri karşılayıp karşılamadığını, öğrencilerin bilişsel gelişimine uygun olup olmadığını ortaya çıkarmaktır. Bu amaç doğrultusunda hedeflenen olgu ve olgular hakkında bilgi içeren kitaplar belge (doküman) incelemesi deseni kullanılarak analiz edilmiştir. Araştırmanın çalışma grubunu Türkiye'de Millı̂ Eğitim Bakanlığı tarafından, 2017- 2018 yılında okutulan ilkokul matematik ders ve öğrenci çalışma kitaplarında bulunan 444 ünite değerlendirme sorusu oluşturmaktadır. Veriler, betimsel analize tâbi tutulmuştur. Araştırma sonuçları; incelenen ünite değerlendirme sorularının üst bilişsel bilgi haricindeki basamaklara çeşitli oranlarda dağıldığını, 1 ve 2. sınıf ders kitaplarındaki soruların tamamının alt düzey bilişsel becerileri ölçtüğünü, 3 ve 4 . sınıf ders kitaplarındaki soruların büyük bir bölümünün alt düzey bilişsel becerileri ölçtüğünü, Yenilenmiş Bloom Taksonomisi'nin bilişsel süreç boyutunun düzeyleri (alt-üst) ve ders kitaplarının düzeyleri (sınıf) arasındaki ilişkinin anlamlı olduğunu ortaya koymuştur.
\end{abstract}

Anahtar Kelimeler: Yenilenmiş bloom taksonomisi, matematik ders kitapları, matematik ölçme ve değerlendirme

Abstract: The aim of this research is to classify the unit evaluation questions in primary school 1st, 2nd,
3rd and 4th grade mathematics course and workbooks in terms of knowledge accumulation dimension and
cognitive process dimension using the Revised Bloom Taxonomy. It is also to determine whether these
activities have the potential to contribute to the development of high-level cognitive skills and whether they
can contain information appropriate to the student's cognitive development. In the research, document
review was used from the patterns of the qualitative research model. The data of the study was gathered
from the 444 unit evaluation questions in the mathematics course books used at the 1st, 2nd, 3rd, and 4th
classes of state primary schools in $2017-2018$ education year. In data analysis, descriptive analysis was
used. Results of the study; questions are distributed in various ratios to the steps other than meta cognitive
information. All of the 1 st and 2nd grade questions measure low-level cognitive skills. The majority of
questions 3 and 4 measure lower-level cognitive skills. It gives a meaningful relationship between levels of
cognitive process dimension and levels of textbooks. Keywords: Revised bloom's taxonomy, mathematics course books, mathematics assessment and evaluation

Giriş

Kalıc1 bir öğrenme gerçekleştirme, öğrencilerin bilişsel becerilerini güçlendirmekle ilişkilendirilebilir. Bilişsel beceriler, akademik konuları başarıyla öğrenmek için ihtiyaç

\footnotetext{
*Bu çalışma 11-14 Nisan 2018'de gerçekleştirilen 17. Uluslararası Sınıf Öğretmenliği Sempozyumu'nda sözlü bildiri olarak sunulmuştur.

**Doç. Dr., Mersin Üniversitesi, Eğitim Fakültesi, Mersin-Türkiye, ORCID: 0000-0003-1705-1325, e -posta: lutfiuredi@gmail.com

***Doktora Öğrencisi, Çukurova Üniversitesi, Sosyal Bilimler Enstitüsü, Adana-Türkiye, ORCID: 0000-0002-1398-

6935, e-posta: hakanulum@gmail.com
} 
duyduğumuz zihinsel yeteneklerdir. Temel bilişsel beceriler, problemleri etkili ve kolay bir şekilde okumak, düşünmek, sıralamak, anlamak, planlamak, hatırlamak ve çözmek için önemlidir. Bilişsel beceriler zayıf olduğunda akademik bilgilerin öğrenilmesi bir mücadele olabilirken, bilişsel beceriler güçlü olduğunda, akademik bilgilerin öğrenilmesi hızlı, kolay, verimli ve eğlenceli bir hal alır.

Akademik bilginin zihne iyi işlenmesi ve yapılandırılması, öğrenmeyi öğrenme, yaratıcı düşünme, eleştirel düşünme, yansitıcı düşünme gibi üst düzey zihinsel becerilerin geliştirilmesine bağlıdır. Bu açıdan son zamanlarda öğrencilerin üst düzey becerilerini geliştirme konusuna önem verilmektedir (Güneş, 2012). Bu becerilerden "öğrenmeyi öğrenme" olarak da ifade edilen üst düzey düşünme becerisinin kazanımına oldukça fazla vurgu yapılmaktadır (Mayer-Sommer, 1990; Sprouse, 1989; Wyatt, 1989). Bu beklentiye ulaşmak için öğrenme faaliyetlerinde sıkça kullanılan metin materyallerinin üst düzey zihinsel faaliyetleri kazandırmaya yönelik değişmesi gerektiği vurgulanmaktadır (Patten ve Williams, 1990; Williams, 1991).

Öğretim faaliyetlerinde en yaygın kullanılan metin materyalleri arasında ders ve çalışma kitapları vardır. Türkiye'de ki öğrencilerin \%8,5'u özel okula gitmektedir (DW, 2020). Özel okullar ders ve çalışma kitaplarını kendileri belirlerken devlet okullarında sınıflarda ortak ve zorunlu olarak ders ve çalışma kitapları kullanılmaktadır. Bu bağlamda Türkiye' de kullanılan en yaygın eğitim aracı ders ve çalışma kitaplarıdır diyebiliriz. Ders ve çalışma kitaplarını iyi analiz edebilmek için öğretim programlarını iyi anlamak gereklidir. 2005 yılından itibaren dünyadaki gelişmeleri dikkate alan Milli Eğitim Bakanlığı (MEB.) öğretim programlarını hazırlarken davranışçı yaklaşım içeren eğitim anlayışından uzaklaşarak yapısalcı eğitim anlayışını benimsemiştir. $\mathrm{Bu}$ anlayışla hazırlanan öğretim programlarının içerisinde öğrencilerin zihinsel yeteneklerinin gelişiminin desteklenmesi, alt düzey zihinsel becerilerinin olduğu kadar üst düzey zihinsel becerilerinin gelişiminin de sağlanması vurgulanmıştır (örneğin 2018 yılında hazırlanan İlkokul Matematik Dersi Öğretim Programı (İMDÖP) (MEB, 2018)). Vurgulanan bu noktanın öğretim programlarının temel ögelerinden, öğrenme ve öğretme faaliyetlerinin önemli bir unsuru olan ölçme ve değerlendirme ögesinin önemli uygulama araçları arasında olan ders ve çalışma kitaplarındaki sorulara yansıması beklenir. Unutulmamalıdır ki ders ve çalışma kitaplarında öğretim programlarının içeriğinin \%100'üne yakınının yansıması görülür. Bu bağlamda öğrencilerin zihinsel yeteneklerinin gelişimini sağlama açısından ders ve çalışma kitaplarının iyi değerlendirilmesi gerekir. Ancak Davidson ve Baldwin'inde (2005) yaptığı çalışmada görüldüğü üzere ders ve çalışma kitaplarında anlamlı bir değişikliğin meydana gelip gelmediğini irdeleyen çalışmalar alan yazında yeterince önem görmemiştir. Genel olarak, ders ve çalışma kitaplarının eğitimindeki rolüne ilişkkin, araştırma ilgisi çok azdır veya hiç yoktur.

$\mathrm{Bu}$ çalışma kapsamında yapılan literatür taramasında matematik alanında, ilkokul düzeyindeki kitaplarda bulunan ünite değerlendirme sorularını değerlendiren bir çalışmaya rastlanmamıştır. Yukarıdaki açıklamalardan da anlaşılacağı üzere bu materyallerin, öğrencilerin matematik derslerinde geliştirecekleri bilişsel beceri setinde çok önemli bir rol oynayabileceği muhtemeldir ve kitapların içeriğine yerleştirilmiş beceri seviyelerini değerlendirmek önemlidir. Yapılacak değerlendirme çalışmalarında da taksonomiler önemli rol oynarlar.

Bilim insanları bilişsel alanda hedefler oluşturup, değerlendirmek amaciyla farklı taksonomiler geliştirmişlerdir. $\mathrm{Bu}$ taksonomiler hedeflere göre soruların oluşturulmasında rehberlik ederler. Ensar (2002), taksonomilerin soru oluşumunda sistem görevini gördüğünü belirtir. Bu sistemde öğretmenler, olguları ve terimleri pratik ve hızlıca düzenleyebilirler. Taksonomiler davranışa yönelik daha somut ifadeler içerdiği için, öğrenci davranışlarını ayarlamada, ölçmede ve takip etmede işimizi kolaylaştırırlar. Belirli bir düzen içerisinde hazırlanan taksonomiler: "Öğrenciler tam olarak, net bir biçimde anladığı zaman veya aklında pürüzler kaldığı, anlamadığı zaman nasıl bir davranış sergiler?” sorusuna cevap arar ve öğretmenlere yardımcı olur. Özellikle Bloom Taksonomisi eğitim süreci içerisinde yaygın olarak bilişsel alan ile ilgili kullanılmaktadır.

Bloom' un Taksonomisi, üç temel düzeyden oluşan (bilişsel, duyuşsal ve psikomotor) bir sistematik sınıflandırmadır (Bloom ve diğerleri, 1956). Geliştirildiği yıllarda eğitime yön veren programların temelinin daha çok davranışçı öğrenme yaklaşımına dayandığı görülmektedir. 
Günümüzde ise hümanisttik psikolojiyi vurgulayan, yapısalcı kurama dayalı ve öğrenci merkezli yaklaşımlar eğitim programlarına yansımaktadır. Buna bağlı olarak Orijinal Bloom Taksonomisi'nin (OBT) etkisi günümüzde azalmıştır. OBT, yapılandırmacı yaklaşımın temelinde bulunan; öğrenci merkezli eğitim, aktif öğrenme, etkin bireysel katılım, bilginin keşfedilip yapılandırılması vb. becerileri kendi yapısı ile kaynaştıramaz olmuştur. OBT yapılandırmacı felsefenin beklentisi olan üst düzey zihinsel becerileri tam olarak ölçmede yetersiz kalmıştır (Amer, 2006; Anderson ve Krathwohl, 2001; Ar1, 2011; Ayvac1 ve Türkdoğan, 2010). Bunun üzerine OBT'nin yenilenmesi ihtiyacı duyulmuş ve bilim insanları harekete geçmiştir. OBT'nin revize edilmesi işini üstlenen bilim insanları bunu yaparken temel bir yaklaşımı benimsemişler ve bu yaklaşımın sınırlarını şu şekilde çizmişıler.

1.Bloom Taksonomisinin orijinalinin incelenip, kapsamının genişletilmesi,

2.Ortak bir dil kullanılması,

3.Günümüzdeki psikolojik gereksinimlere ve okullara uygun olmas1, 2014).

4.Uygulamaya yönelik örneklerle yaklaşımın güçlendirilmesi (Anderson ve Krathwohl,

$\mathrm{Bu}$ sınırlılıklar içerisinde hazırlanan Yenilenmiş Bloom Taksonomisi (YBT) Bloom'un eski bir öğrencisi olan Lorin Anderson öncülüğünde, psikologlar, eğitim programc1ları, ölçme ve değerlendirme uzmanları ve eğitim araştırmacıları ile birlikte hazırlanmıştır (Anderson ve Krathwohl, 2001). YBT'de üç geniş kategoride değişiklik yapılmıştır: terminoloji, yapı ve vurgu (Forehands, 2010). Şekil 1'de bu değişiklikleri görmek mümkündür.

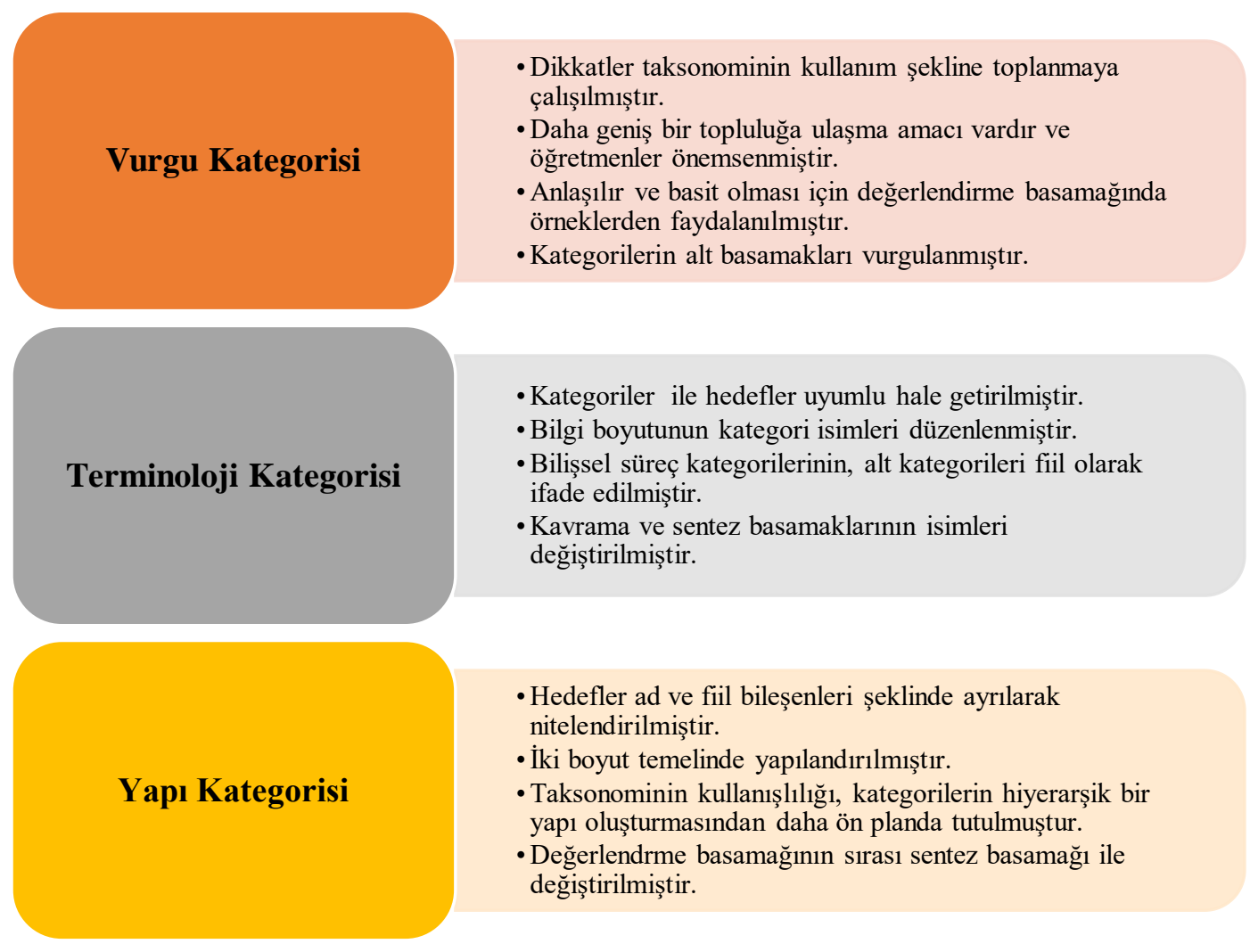

Şekil 1. OBT'de Yapılan Değişikliklerin Özeti (Anderson ve Krathwohl, 2014).

YBT'de en dikkat çeken değişiklikler yapısal kategoride olanlardır Şekil 2'de bu değişikliklerin özeti görülmektedir. Yapısal değişikliklerle YBT iki boyutlu hale getirilmiştir. Oluşturulan iki boyut şunlardır:

1) Bilgi birikimi boyutu (veya öğrenilecek bilgi türü) ve 
2) Bilişsel süreç boyutu (veya bilgi edinmede kullanılacak bilişsel süreçler) (Anderson ve Krathwohl, 2001).

Bilgi birikimi boyutu dört bilgi türünden oluşmaktadır: olgusal, kavramsal, işlemsel ve üst-bilişsel bilgi kategorilerinden oluşur. Bilişsel süreç boyutu ise altı kategoriden oluşur: hatırlama, anlama, uygulama, çözümleme, değerlendirme ve yaratma.

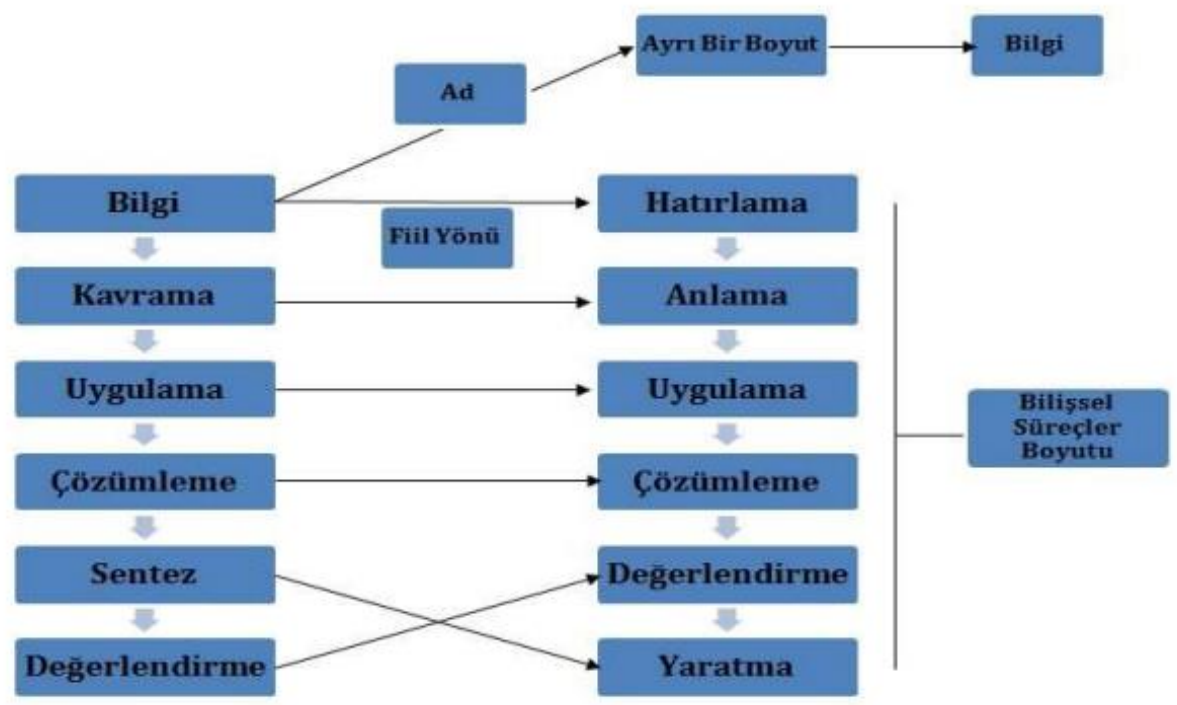

Şekil 2. Taksonominin ilk şeklinden güncelleştirilmiş biçimine geçilirken yapılan değişikliklerin özeti (Anderson ve Krathwohl, 2014, s. 356).

Bilişsel süreç kategorilerinin, alt kategorileri fiil olarak ifade edilen YBT'de oluşan yeni terimler şu şekilde tanımlanır (Forehand, 2010):

- Hatırlama: Uzun süreli hafızadan ilgili bilgileri alma, tanıma ve çağırma.

- Anlama: Sözlü, yazılı ve grafiksel mesajlardan yorumlama, örnekleme, sinıflandırma, özetleme, çıkarım, karşılaştırma ve açıklama yoluyla anlam oluşturmak.

- Uygulama: Bir prosedürü yürütme veya uygulama yoluyla yürütme veya kullanma.

- Analiz: Temel parçalara ayırmak, parçaların birbiriyle ve genel bir yapı ya da amaç ile ilişkisini farklılaştırmak, organize etmek ve ilişkilendirmek yoluyla nasıl ilişkilendirdiğini belirlemek.

- Değerlendirme: Kontrol ve eleştiri yoluyla ölçüt ve standartlara göre karar verme.

- Yaratma: Tutarlı veya işlevsel bir bütün oluşturmak için unsurları bir araya getirmek; üreterek, planlayarak veya üreterek öğeleri yeni bir örüntü veya yapıda yeniden organize etmek.

YBT, etkinliklerin bilişsel açısından değerlendirilmesinde yararlanılan önemli bir araçtır. Yenilenen taksonomi, öğretim hedeflerini ve etkinliklerini oluşturmak, ölçme ve değerlendirme yapmak için önemli bir kılavuzdur. Ayrıca önceden oluşturulan hedeflerin ve etkinliklerin, ölçme ve değerlendirme araçlarının bilişsel beceriler açısından nerede olduğunun belirlenmesinde önem arz eder (Krathwohl, 2002).

Çalışmanın sonunda araştırmaya dâhil edilen ilkokul Matematik Ders ve Çalışma Kitaplarında (MDÇK) bulunan ünite değerlendirme sorularının yeterince bilişsel becerileri kapsayıp kapsamadığını ortaya çıkarmak amaçlanmıştır. Buradan, üst düzey düşünme becerilerini teşvik eden İMDÖP'ün ilkokul MDÇK hazırlanırken göz önünde bulundurulup bulundurulmadı yönünde bir yargıya varılabilecektir.

Çalışmada alternatif olarak, "eğer ilkokul MDÇK'ya bilişsel beceriler dengeli bir şekilde dağılmış ise öğretmenlerin bu eğitim materyallerine büyük ölçüde güveni sağlanabilir" düşüncesinden hareketle sonuçların betimlenmesi önemli görülmektedir. 


\section{Araştırmanın amacı}

Bu araştırmanın amacı Türkiye'de ilkokullarda (1, 2, 3 ve 4. sınıf) kullanılan MDÇK ünite değerlendirme sorularını YBT'nin bilgi birikimi boyutu ve bilişsel süreç boyutu basamaklarına göre dağılımını incelemektir. Alt başlıklar sırasıyla aşağıdaki şekilde biçimlendirilmelidir:

\section{Araştırma problemi}

İlkokul 1, 2, 3 ve 4. sınıf MDÇK' de yer alan ünite değerlendirme soruları:

1. YBT'nin bilgi birikimi boyutu ve bilişsel süreç boyutu basamaklarına göre nasıl dağılım gösterir?

2. YBT'nin alt düzey ve üst düzey bilişsel beceri basamaklarına göre nasıl dağılım gösterir?

3. YBT'nin alt düzey ve üst düzey bilişsel beceri basamaklarına dağılımında, sınıf seviyesine göre anlamlı farklılık var mıdır?

\section{Yöntem}

Araştırmada, doküman incelemesi deseninden faydalanılmıştır. Doküman incelemesi nitel araştırma modelinin desenlerindendir. $\mathrm{Bu}$ desen ile araştırmaya kaynaklık eden, araştırma konusunu yansıtan belgeler incelenerek verilere ulaşılması hedeflenmiştir.

\section{Çalışma grubu}

Nitel araştırmalarda genelde amaçlı bir örneklem belirlenir. Buradaki amaç araştırmaya kaynaklık eden, araştırma konusunu yansitan durumları derinlemesine analiz edebilmektir. Böylece bilgi zenginliği sağlayarak araştırmaya anlam yüklenebilir (Patton, 2014, s. 46). Araştırmanın çalışma grubu, bu durum ve araştırmanın amacı göz önüne alınarak Millî Eğitim Bakanlığının birincil kaynaklar olarak belirlediği ders ve çalışma kitapları olarak belirlenmiştir. Bu araştırmanın evrenini, Türkiye'de ilkokullarda okutulan MDÇK' de bulunan ünite değerlendirme soruları oluşturmaktadır. Araştırmanın çalışma grubunu ise ilkokullarında 2017- 2018 yılında okutulan 1, 2, 3 ve 4. sınıf MDÇK' de bulunan ünite değerlendirme soruları oluşturmaktadır. Aşağıda, Tablo 1 'de araştırmanın çalışma grubunun sınıflara göre dağılımı verilmektedir.

Tablo 1.

MDÇK'de Yer Alan Ünite Değerlendirme Soru Sayısı

\begin{tabular}{lc}
\hline Kitap & Ünite Değerlendirme Soru Sayıs1 \\
\hline İlköğretim 1. Sinıf MDÇK & 65 \\
İlköğretim 2. Sınıf MDÇK & 49 \\
İlköğretim 3. Sınıf MDÇK & 134 \\
İlköğretim 4. Sınıf MDÇK & 196 \\
Toplam & 444 \\
\hline
\end{tabular}

\section{Verilerin toplanması}

Ünite değerlendirme sorularının YBT Belirtke Tablosuna uygun ve doğru bir şekilde yerleştirilmesi için iki adet anahtar tablo kullanılmıştır.

İlk anahtar tablo araştırmacılar tarafindan hazırlanmıştır (bknz. ek 1). Bu tablo ile ünite değerlendirme sorularının, YBT Belirtke Tablosunda bilgi boyutu basamaklarına doğru ve kolay yerleştirilmesi amaçlanmıştır. Tabloyu hazırlarken Anderson ve Krathwohl'ün (2014) editörlüğünde hazırlanan kitapta (Çevirmeni Durmuş Ali Özçelik) bulunan "YBT Belirtke Tablosu", ilkokul matematiğine uygun olarak revize edilmiştir. Veri toplama aracının geçerliği için ikisi Eğitim Programları ve Öğretimi, ikisi İngiliz Dili ve Eğitimi alanından olmak üzere üç akademisyenden görüş alınmıştır.

İkinci anahtar tablo ile ünite değerlendirme sorularının, YBT Belirtke Tablosunda bilişsel beceri boyutu basamaklarına doğru ve kolay yerleştirilmesi amaçlanmıştır. Anahtar tablo Ulum ve Taşkaya'nın (2019) araştırmasında kullandığı tablodur. Tablonun kullanılması için araştırmacılardan gerekli izinler alınmıştır. Ulum ve Taşkaya (2019) anahtar tabloyu Bloom ve 
diğerleri (1956) tarafından orijinal taksonomi kitabının gözden geçirilip ön bilgiler toplanarak sonrasında ise Anderson ve Krathwohl'ün (2014) editörlüğünde hazırlanan kitap (Çev. Durmuş Ali Özçelik) ile David R. Krathwohl'un (2002) araştırmasından faydalanarak oluşturduklarını belirtmişlerdir. Oluşturulan bu tablo bilişsel süreç boyutundaki becerilerin vurgulamaya çalıştığ 1 fiilleri İngilizceden İngilizceye sözlük eşliğinde Türkçeye çevrilmesi ile sağlanmıştır. Burada ana kategorilerdeki fiillerin gerçek anlamlarından kaymamasını sağlanmaya çalışılmıştır. Araştırmacılar İngiliz Dili ve Eğitimi, Mütercim ve Tercümanlık ve Eğitim Programları ve Öğretimi alanından olmak üzere üç akademisyenden geçerliği sağlamak için uzman görüşü almışlardır.

\section{Verilerin analizi}

Araştırma kapsamında toplanan verilere betimsel analiz uygulanmıştır. Yıldırım ve Şimşek'e (2013) göre betimsel analiz; araştırma için toplanan verilerin, önceden saptanmış temalara göre özünü yansıtmak ve yorumlamaktır. Betimsel analiz bir takım aşamalar dâhilinde yapılmalıdır. $\mathrm{Bu}$ araştırmada öncelikle betimsel analiz için bir çerçeve belirlenmiş, oluşturulan bu çerçeveye göre veriler işlenmiş, bulgular tanımlanmış ve yorumlanmıştır. Analiz bu aşamalar çerçevesinde yürütülmüştür. Tablo 2'de bu aşamalar açıklanmıştır.

Tablo 2.

Betimsel Analiz Aşamalarının Araştırmada Uygulanması

\begin{tabular}{l} 
Tema çerçevesi belirleme \\
\hline YBT'nin (araştırmanın kuramsal çerçevesi) bilgi boyutu (olgusal bilgi, kavramsal bilgi, \\
işlemsel bilgi ve üst-bilişsel bilgi) ve bilişsel süreç boyutu (hatırlama, anlama, uygulama, \\
çözümleme, değerlendirme ve yaratma) basamakları araştırmanın tema çerçevesi olarak \\
belirlenmiştir.
\end{tabular}

\section{Oluşturulan çerçeveye verilerin işlenmesi}

Bu aşamada temalara (bilgi boyutu ve bilişsel süreç boyutu) İlkokul 1, 2, 3 ve 4. sınıf MDÇK'de yer alan ünite değerlendirme soruları bağımsız olarak iki araştırmacı tarafından YBT belirtke tablosuna yerleştirilmiştir. Yerleştirme işleminden sonra güvenirlik çalışması yapılmıştır. Araştırmanın bu aşamasında güvenirlik "uzlaşma oranı (agreement rate)" (AR) kullanılarak sağlanmıştır (Orwin \& Vevea, 2009). AR değeri "0" ile "1" arasında değişir. 0.80 ve üzeri değer birçok ölçme ve değerlendirme uzmanı tarafından kabul görür. Uzlaşma oranı için $A R=$ üzerinde uzlaşılan görüş sayısı / toplam görüşs sayısı formülü kullanılır (Orwin \& Vevea, 2009). Araştırmanın yazarları tarafından bağımsız olarak 444 ünite değerlendirme sorusunun bilişsel süreç boyutunda yer alan fiil ifadesi ve bilgi boyutunda yer alan ad ifadesine göre kodlanmasıyla oluşan AR değeri 0.85 olarak hesaplanmıştır. Araştırmacılar 380 soruyu belirtke tablosuna yerleştirirken uyum göstermiştir. Uyum sağlanamayan sorular üzerinde veri toplama bölümünde bahsi geçen anahtar tablolar yardımıyla araştırmacılar tartışmış ve ortak görüşe varmışlardır. Bu şekilde araştırmanın güvenirliği sağlanmıştır.

Araştırmanın geçerliği kapsamında iki uzmandan görüş alınmıştır. Uzmanlar Eğitim Programları ve Öğretim alanındandır. Alan uzmanları YBT tablosuna yerleştirilen değerlendirme sorularının uygunluğu açısından görüş bildirmiş ve yapılan kodlamaların uygunluğunu teyit etmiştir.

\section{Bulguları tanımlama}

Ulaşılan verilerin tanımlanması ve desteklenmesi aşamasıdır (Yıldırım ve Şimşek, 2013). Veriler, araştırmanın alt problemlerine uygun şekilde tanımlanmıştır. Örneğin 2. Araştırma alt problemi doğrultusunda, alt veya üst düzey bilişsel beceri basamaklarına tüm değerlendirme soruları tanımlanmıştır. Bunun yanında SPSS 25 (Statistical Package for the Social Sciences) istatistik paket programı yardımı ile sıklık, yüzde ve iki değişken için iki yönlü kay-kare testi analizi yoluyla sayısallaştırarak tablolarla desteklenmiştir.

\section{Bulguları yorumlama}

Tanımlanan ve tablolarla desteklenen veriler yorumlanmış ve alanyazın ile ilişkilendirilmiştir. 


\section{Bulgular}

Araştırma kapsamında elde edilen bulgular, araştırma sorularına uygun, cevap oluşturacak şekilde aşağıda sunulmuştur.

Tablo 3.

İlkokul 1. sınıf MDÇK'de Yer Alan Ünite Değerlendirme Sorularının YBT’nin Bilgi Birikimi ve Bilişsel Süreç Boyutu Basamaklarına Dağılımı

\begin{tabular}{llllll}
\hline \multirow{2}{*}{ S. Sinıf } & $\mathrm{f}$ & & \multirow{2}{*}{ Toplam } & $\%$ \\
\cline { 2 - 5 } & Olgusal & Kavramsal & İşlemsel & & $\%$ \\
\hline Hatırlama & 37 & - & - & 37 & 57 \\
Anlama & 1 & 1 & 26 & 28 & 43 \\
Toplam & 38 & 1 & 26 & 65 & 100 \\
$\%$ & 58.50 & 1.50 & 40 & & \\
\hline
\end{tabular}

1. sınıf düzeyindeki MDÇK yer alan ünite değerlendirme soruları, YBT'nin bilgi birikimi boyutu açısından incelendiğinde ünite değerlendirme soruları, bilgi birikimi basamaklarından olgusal, kavramsal ve işlemsel bilgi basamaklarına dağılım gösterirken üst bilişsel bilgi basamağında herhangi bir soru yer almamıştır. Oluşan dağ 1 lım şu şekildedir; toplam 65 ünite değerlendirme sorusunun $(\% 100)$, 38'i $(\% 58,5)$ olgusal bilgi, 1'i $(\% 1,5)$ kavramsal bilgi, 26's1 (\%40) ise işlemsel bilgi birikimi basamaklarındadır.

1. sınıf düzeyindeki MDÇK yer alan ünite değerlendirme soruları, YBT’nin bilişsel beceri boyutu açısından incelendiğinde; ünite değerlendirme soruları bilişsel beceri boyutu basamaklarından sadece hatırlama ve anlama basamaklarına dağılım göstermiştir. Uygulama, çözümleme, değerlendirme, yaratma ve yaratma basamaklarında sorular yoktur. 1. sinıf düzeyindeki MDÇK 'de bulunan toplam 65 (\%100) ünite değerlendirme sorusunun 37'si (\%57) hatırlama, 28'i (\%43) anlama basamaklarındadır.

Bilgi birikimi boyutu ile bilişsel süreç boyutunun kesişimine bakacak olursak; olgusal bilgi basamağında bulunan 37 sorunun hatırlama basamağında yer alırken, 1 sorunun anlama basamağında yer aldığını; kavramsal bilgi basamağında bulunan 1 sorunun anlama basamağında yer alırken hatırlama basamağında sorunun yer almadığını; işlemsel bilgi basamağında bulunan 26 sorunun tamamı anlama basamağında yer alırken hatırlama basamağında sorunun yer almadığını görebiliriz.

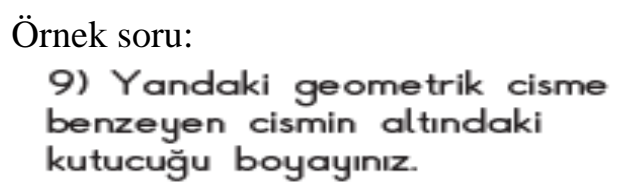

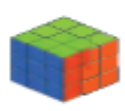
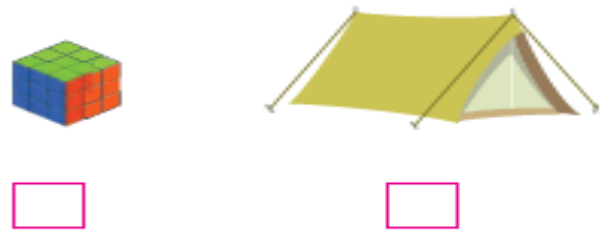
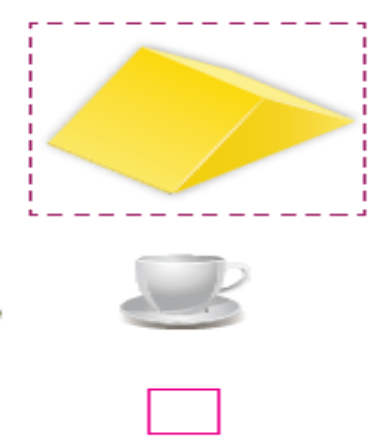

Yukarıdaki soru "matematiksel nesneleri ayırt etme" niteliği taşıdığından bilgi birikimi boyutlarından olgusal bilgi basamağında ve "benzerini seçmek" söz konusu olduğundan bilişsel süreç boyutu açısından hatırlama basamağındadır diyebiliriz (anahtar tablolardan yararlanarak analiz edilmiş̧tir). 
Tablo 4.

İlkokul 2. Sınıf MDÇK'de Yer Alan Ünite Değerlendirme Sorularının YBT'nin Bilgi Birikimi ve Bilişsel Süreç Boyutu Basamaklarına Dağılımı

\begin{tabular}{llllll}
\hline \multirow{2}{*}{2. Sinif } & $\mathrm{f}$ & & Toplam & $\%$ \\
\cline { 2 - 4 } & Olgusal & Kavramsal & İşlemsel & & \\
\hline Hatırlama & 18 & 2 & - & 20 & 41 \\
Anlama & - & - & 29 & 29 & 59 \\
Toplam & 18 & 2 & 29 & 49 & 100 \\
$\%$ & 37 & 4 & 59 & - & \\
\hline
\end{tabular}

2. sınıf düzeyindeki MDÇK yer alan ünite değerlendirme soruları, YBT'nin bilgi birikimi boyutu açısından incelendiğinde ünite değerlendirme soruları, bilgi birikimi basamaklarından olgusal, kavramsal ve işlemsel bilgi basamaklarına dağılım gösterirken üst bilişsel bilgi basamağında herhangi bir soru yer almamıştır. Dağılım şu şekildedir; toplam 49 ünite değerlendirme sorusunun (\%100), 18'i (\%37) olgusal bilgi, 2'si (\%4) kavramsal bilgi, 29'u (\%59) ise işlemsel bilgi birikimi basamaklarındadır.

2. sınıf düzeyindeki MDÇK yer alan ünite değerlendirme soruları, YBT'nin bilişsel beceri boyutu açısından incelendiğinde; ünite değerlendirme soruları bilişsel beceri boyutu basamaklarından sadece hatırlama ve anlama basamaklarına dağılım göstermiştir. Uygulama, çözümleme, değerlendirme, yaratma ve yaratma basamaklarında sorular yoktur. 2. sinıf düzeyindeki MDÇK'de bulunan toplam 49 (\%100) ünite değerlendirme sorusunun 20'si (\%41) hatırlama, 29'u (\%59) anlama basamaklarındadır.

Bilgi birikimi boyutu ile bilişsel süreç boyutunun kesişimine bakacak olursak; olgusal bilgi basamağında bulunan 18 sorunun tamamı hatırlama basamağında yer alırken, anlama basamağında sorunun yer almadığını; kavramsal bilgi basamağında bulunan 2 sorunun tamamı hatırlama basamağında yer alırken anlama basamağında sorunun yer almadığını; işlemsel bilgi basamağında bulunan 29 sorunun tamamı anlama basamağında yer alırken hatırlama basamağında sorunun yer almadığını görebiliriz.

Örnek soru:

6. Gökay in 54 lirası vardr. Selin in parası ise Gökayin parasından 21 lira eksiktir. Ikisinin toplam kaç lirası vardır? İșlem yaparak gösteriniz.

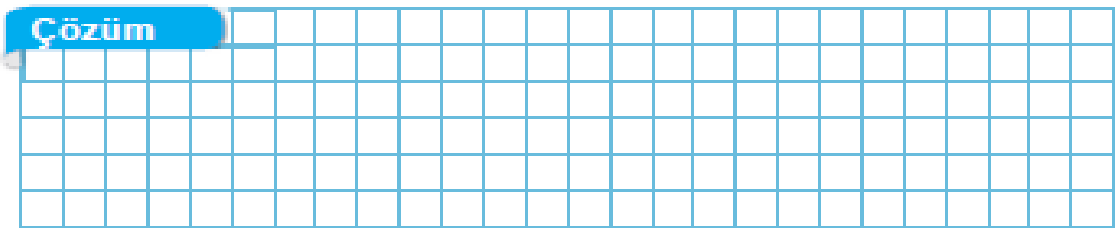

Yukarıdaki soru "tamsayı, kesir, cebirsel ifadelerde dört işlem bilgisi" niteliği taşıdığından bilgi birikimi boyutlarından işlemsel bilgi basamağında ve "verilen problem doğrultusunda uygun işlemi belirleme" söz konusu olduğundan bilişsel süreç boyutu açısından anlama basamağında yer aldığını söyleyebiliriz (anahtar tablolardan yararlanarak analiz edilmiştir). 
Tablo 5.

İlkokul 3. sınıf MDÇK' de Yer Alan Ünite Değerlendirme Sorularının YBT'nin Bilgi Birikimi ve Bilişsel Süreç Boyutu Basamaklarına Dağılımı

\begin{tabular}{|c|c|c|c|c|c|}
\hline \multirow{2}{*}{ 3. Sinif } & \multicolumn{3}{|l|}{$\mathrm{f}$} & \multirow{2}{*}{ Toplam } & \multirow{2}{*}{$\%$} \\
\hline & Olgusal & Kavramsal & İșlemsel & & \\
\hline Hatırlama & 47 & 3 & - & 50 & 37 \\
\hline Anlama & 10 & 3 & 57 & 70 & 53 \\
\hline Uygulama & - & - & 7 & 7 & 5 \\
\hline Yaratma & - & 1 & 6 & 7 & 5 \\
\hline Toplam & 57 & 7 & 70 & 134 & 100 \\
\hline$\%$ & 43 & 5 & 52 & - & 100 \\
\hline
\end{tabular}

3. sınıf düzeyindeki MDÇK yer alan ünite değerlendirme soruları, YBT'nin bilgi birikimi boyutu açısından incelendiğinde ünite değerlendirme soruları, bilgi birikimi basamaklarından olgusal, kavramsal ve işlemsel bilgi basamaklarına dağ 1 lım gösterirken üst bilişsel bilgi basamağında herhangi bir soru yer almamıştır. Bu dağılım şu şekildedir; toplam 134 ünite değerlendirme sorusunun (\%100), 57'si (\%43) olgusal bilgi, 7'si (\%5) kavramsal bilgi, 70'i (\%52) ise ișlemsel bilgi birikimi basamaklarındadır.

3. sınıf düzeyindeki MDÇK yer alan ünite değerlendirme soruları, YBT’nin bilişsel beceri boyutu açısından incelendiğinde; ünite değerlendirme soruları bilişsel beceri boyutu basamaklarından hatırlama, anlama, uygulama ve yaratıcılık basamaklarına dağılım gösterirken, çözümleme ve değerlendirme basamaklarında soru yoktur. 3. sınıf düzeyindeki MDÇK'de bulunan toplam 134 (\%100) ünite değerlendirme sorusunun 50'si (\%37) hatırlama, 70'i (\%53) anlama, 7'si (\%5) uygulama, 7'si (\%5) yaratma basamaklarındadır.

Bilgi birikimi boyutu ile bilişsel süreç boyutunun kesişimine bakacak olursak; olgusal bilgi basamağında bulunan 47 soru hatırlama basamağında yer alırken, anlama basamağında 10 sorunun yer aldığını, diğer basamaklarda soru olmadığını; kavramsal bilgi basamağında bulunan sorulardan 3'nün hatırlama, 3'nün anlama, 1'nin yaratıcıllk basamağında yer alırken, diğer basamaklarda soru olmadığını; işlemsel bilgi basamağında bulunan 57 sorunun anlama basamağında yer alırken 7'sinin uygulama, 6'sının yaratıcılık basamağında olduğunu, diğer basamaklarda soru olmadığını görebiliriz.

Örnek soru:

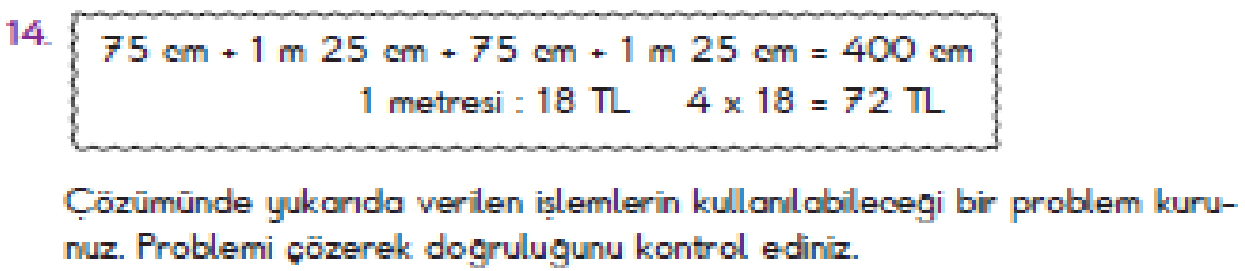

Yukarıdaki soru "tamsayı, kesir, cebirsel ifadelerde dört işlem bilgisi" niteliği taşıdığından bilgi birikimi boyutlarından işlemsel bilgi basamağında ve "verilen değerlere uygun bir problem oluşturma" söz konusu olduğundan bilişsel süreç boyutu açısından yaratma basamağında yer aldığını söyleyebiliriz (anahtar tablolardan yararlanarak analiz edilmiştir).

4. sınıf düzeyindeki MDÇK yer alan ünite değerlendirme soruları, YBT'nin bilgi birikimi boyutu açısından incelendiğinde ünite değerlendirme soruları, bilgi birikimi basamaklarından olgusal, kavramsal ve ișlemsel bilgi basamaklarına dağ 1 lım gösterirken üst bilișsel bilgi basamağında herhangi bir soru yer almamıştır. Dağılım şu şekildedir; toplam 196 ünite değerlendirme sorusunun (\%100), 83'ü (\%42.5) olgusal bilgi, 9'u (\%4.5) kavramsal bilgi, 104'ü (\%53) ise işlemsel bilgi birikimi basamaklarındadır. 
Tablo 6.

İlkokul 4. Sınıf MDÇK'de Yer Alan Ünite Değerlendirme Sorularının YBT'nin Bilgi Birikimi ve Bilişsel Süreç Boyutu Basamaklarına Dağılımı

\begin{tabular}{llllll}
\cline { 1 - 3 } 4. Sinıf & $\mathrm{f}$ & & Toplam & $\%$ \\
\cline { 2 - 4 } & Olgusal & Kavramsal & İşlemsel & & \\
\hline Hatırlama & 77 & 4 & - & 81 & 41.50 \\
Anlama & 3 & 5 & 104 & 112 & 57 \\
Uygulama & 1 & - & - & 1 & .50 \\
Yaratma & 2 & - & - & 2 & 1 \\
Toplam & 83 & 9 & 104 & 196 & 100 \\
$\%$ & 42.50 & 4.50 & 53 & - & \\
\hline
\end{tabular}

4. sınıf düzeyindeki MDÇK yer alan ünite değerlendirme soruları, YBT’nin bilişsel beceri boyutu açısından incelendiğinde; ünite değerlendirme soruları bilişsel beceri boyutu basamaklarından hatırlama, anlama, uygulama ve yaratıcılık basamaklarına dağılım gösterirken, çözümleme ve değerlendirme basamaklarında soru yoktur. 4. sınıf düzeyindeki MDÇK 'de bulunan toplam 196 (\%100) ünite değerlendirme sorusunun 81'i (\%41.5) hatırlama, 112'si (\%57) anlama, 1'i (\%0.50) uygulama, 2'si (\%1) yaratma basamaklarındadır.

Bilgi birikimi boyutu ile bilişsel süreç boyutunun kesişimine bakacak olursak; olgusal bilgi basamağında bulunan 77 soru hatırlama basamağında yer alırken, anlama basamağında 3, uygulama basamağında 1 , yaratma basamağında 2 sorunun yer aldığını, diğer basamaklarda soru olmadığını; kavramsal bilgi basamağında bulunan sorulardan 4'ü hatırlama, 5'i anlama, basamağında yer alırken, diğer basamaklarda soru olmadığını; işlemsel bilgi basamağında bulunan 104 sorunun tamamının anlama basamağında olduğunu, diğer basamaklarda soru olmadığını görebiliriz.

Örnek

soru:

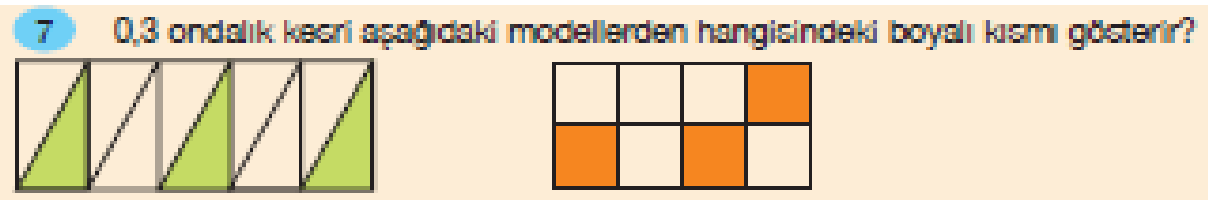

Yukarıdaki soru "tamsayı, kesir, cebirsel ifadelerde dört işlem bilgisi" niteliği taşıdığından bilgi birikimi boyutlarından işlemsel bilgi basamağında ve "sözlü, yazıllı ya da grafik biçimlerinde ifade edilen mesajları yorumlamak" söz konusu olduğundan bilişsel süreç boyutu açısından anlama basamağında yer aldığını söyleyebiliriz (anahtar tablolardan yararlanarak analiz edilmiştir).

Tablo 7.

İlkokul 1, 2, 3 ve 4. Sınıf MDÇK'de Yer Alan Ünite Değerlendirme Sorularının YBT'nin Alt Düzey ve Üst Düzey Bilişsel Beceri Basamaklarına Dağılımının, Sınıf Seviyesine Göre Farklılığ

\begin{tabular}{|c|c|c|c|c|c|c|c|}
\hline \multirow{2}{*}{ Değişkenler } & \multicolumn{7}{|c|}{ Sinif } \\
\hline & & 1. Sinif & 2. Sinif & 3.Sinif & 4. Sinif & $X_{2}$ & $\mathrm{p}$ \\
\hline \multirow{5}{*}{$\begin{array}{l}\text { Alt düzey } \\
\text { bilişsel beceri } \\
\text { basamakları } \\
\text { Üst düzey } \\
\text { bilişsel beceri } \\
\text { basamakları } \\
\text { Toplam }\end{array}$} & $\mathrm{N}$ & 65 & 49 & 128 & 194 & 8,191 & 0.042 \\
\hline & $\%$ & 100 & 100 & 95.50 & 99 & & \\
\hline & $\mathrm{N}$ & - & - & 6 & 2 & & \\
\hline & $\%$ & - & - & 4.50 & 1 & & \\
\hline & $\begin{array}{l}\mathrm{N} \\
\%\end{array}$ & $\begin{array}{l}65 \\
100\end{array}$ & $\begin{array}{l}49 \\
100\end{array}$ & $\begin{array}{l}128 \\
100\end{array}$ & $\begin{array}{l}196 \\
100\end{array}$ & & \\
\hline
\end{tabular}


1. Sınıf MDÇK'de bulunan ünite değerlendirme soruları, YBT'deki bilişsel beceri boyutundaki, alt düzey ve üst düzey bilişsel beceri basamaklarına göre analiz edilirse; 65 (\%100) ünite değerlendirme sorusunun 65'inin de (\%100) alt düzey bilişsel beceri basamaklarına dâhil olduğu, üst düzey bilişsel beceri basamaklarında herhangi bir ünite değerlendirme sorusunun olmadığı görülmektedir.

2. Sınıf MDÇK'de bulunan ünite değerlendirme soruları, YBT'deki bilişsel beceri boyutundaki, alt düzey ve üst düzey bilişsel beceri basamaklarına göre analiz edilirse; 49 (\%100) ünite değerlendirme sorusunun 49'unun da (\%100) alt düzey bilişsel beceri basamaklarına dâhil olduğu, üst düzey bilişsel beceri basamaklarında herhangi bir ünite değerlendirme sorusunun olmadığ 1 görülmektedir.

3. Sınıf MDÇK'de bulunan ünite değerlendirme soruları, YBT'deki bilişsel beceri boyutundaki, alt düzey ve üst düzey bilişsel beceri basamaklarına göre analiz edilirse; 134 (\%100) ünite değerlendirme sorusunun 128'inin (\%95.50) alt düzey bilişsel beceri basamaklarına dâhil olduğu, 6’sının (\%4.50) üst düzey beceri basamaklarına dahil olduğu görülmektedir.

4. Sınıf MDÇK'de bulunan ünite değerlendirme soruları, YBT'deki bilişsel beceri boyutundaki, alt düzey ve üst düzey bilişsel beceri basamaklarına göre analiz edilirse;196 (\%100) ünite değerlendirme sorusunun 194'nün (\%99) alt düzey bilişsel beceri basamaklarına dâhil olduğu, 2'sinin (\%1) üst düzey beceri basamaklarına dâhil olduğu görülmektedir.

1, 2, 3 ve 4. Sınıf MDÇK'de bulunan ünite değerlendirme soruların, YBT'de bulunan bilişsel beceri boyutunun, alt düzey ve üst düzey bilişsel beceri basamaklarına göre dağılımının sınıf düzeyine bakılarak anlamlı bir şekilde farklılaşıp farklılaşmadığına ilişkin kay-kare testi sonuçları tablo 7' de gösterilmiştir. Tablo 7'den tüm sınıf düzeyindeki MDÇK'de bulunan ünite değerlendirme sorularının düzeyi ile YBT'nin bilişsel süreç boyutundaki alt veya üst düzey zihinsel beceriler arasında ilişki olduğu sonucuna varılmaktadır. Bu sonuca göre sınıf düzeyi ile ünite değerlendirme sorularının düzeyi (alt düzey-üst düzey) arasındaki farkın anlamlı olduğunu söyleyebiliriz $\left(\mathrm{X}_{2}(3)=8,191, \mathrm{p}<.05\right)$.

\section{Tartışma, Sonuç ve Öneriler}

Araştırmadan elde edilen bulgular 1 ve 2. sınıf MDÇK'de yer alan ünite değerlendirme sorularının, YBT'nin bilişsel beceri boyutunu oluşturan basamaklarından hatırlama ve anlama basamaklarında; 3 ve 4 . sinıf sorularının hatırlama, anlama, uygulama ve yaratıcılik basamaklarında olduğunu göstermiştir.

Bilgi boyutunu oluşturan tüm basamaklara göre inceleme yapıldığında 1, 2, 3 ve 4 . sınıf MDÇK'de yer alan ünite değerlendirme sorularının dağılımının olgusal ve işlemsel bilgi basamaklarında yoğunlaştığını, kavramsal bilgi basamağında yer alan soruların sınırlı olduğunu, üst bilişsel bilgi basamağında hiç soru olmadığını görebiliriz.

$1,2,3$ ve 4. sınıf düzeyindeki MDÇK'de bulunan ünite değerlendirme soruları, YBT’nin bilişsel beceri boyutunun, alt düzey bilişsel beceri basamakları (hatırlama, anlama, uygulama) ile üst düzey bilişsel beceri basamakları (çözümleme, değerlendirme, yaratma) göz önüne tutularak incelendiğinde; 1 ve 2 . sınıf düzeyinde ünite değerlendirme sorularının tamamının alt düzey bilişsel becerileri ölçtüğü, 3 ve 4. sınıf düzeyinde ki ünite değerlendirme sorularının da neredeyse tamamının alt düzey bilişsel becerileri ölçtüğü anlaşılmaktadır.

Araştırmanın diğer bir sonucu ise ünite değerlendirme sorularının seviyelerinin (sınıf düzeyi) YBT'nin bilişsel süreç boyutu düzeyleri (alt düzey zihinsel becerileri veya üst düzey zihinsel beceriler) arasındaki ilişki hakkındadır. İlkokullarda okutulan MDÇK'de bulunan ünite değerlendirme sorularının seviyesi arttıkça, bilişsel düzeyi de (alt düzeyden üst düzeye) de artmaktadır.

Çalışmada ulaşılan, ünite değerlendirme sorularının üst bilişsel bilgi haricindeki diğer basamaklarda yer aldığı sonucu Piaget'in (1953) gelişim psikolojisi alanındaki kuramıyla tutarlıdır. Şöyle ki: Türkiye'de ilkokula kayıt, çocukların 66 ayını doldurması şartına bağlıdır. Piaget'in (1953) somut işlemler dönemindeki temel alınan yaş grubu (7-11) göz önünde tutulursa, ilkokullara kayıtlı çocukların somut işlemler döneminde olduğu söylenebilir. Bununla beraber YBT’nin bilgi birikimi boyutunun üst bilişsel bilgi basamağında tamamıyla soyutlama söz 
konusudur (Anderson ve Krathwohl, 2014). Bu açıdan somut işlemler döneminde yer alan çocukların cevaplayacağı soruların üst bilişsel bilgi basamağında yer alarak soyutlama içermesi zaten beklenmemelidir.

Araştırmada ulaşılan sonuçlardan ünite değerlendirme sorularının neredeyse tamamının alt düzey zihinsel becerileri ölçtüğü sonucu İMDÖP'ün üst düzey zihinsel becerileri kullanma konusunda yaptığı vurguların gerisinde kalmıştır. İMDÖP'ün (2018) temel alınarak hazırlandığ1 MDÇK'lar üst düzey zihinsel becerileri ölçme noktasında yetersizdir. Oysaki ders ve çalışma kitapları öğretim programlarını tamamen yansıtan araçlar olmalıdır (Arslan ve Özpınar, 2009; Demirel ve Kıroğlu, 2006; Kılıç ve Seven, 2006). MDÇK'lar, İMDÖP'ün üst düzey zihinsel beceriler konusundaki önerileri yansitmamaktadır.

Alan yazın incelendiğinde ders ve çalışma kitaplarında bulunan soruların Bloom'un Orijinal Taksonomi' sine ve YBT' ye göre sınıflandırıldığı ilkokul düzeyinde matematik alanında çalışmaya rastlanmazken aynı alanda farklı seviyelerde veya farklı alanlarda farklı seviyelerde ders kitaplarını inceleyen çalışmalara rastlanmıştır. Köğce ve Baki (2009) yaptıkları araştırmada ÖSS sınavı matematik soruları ile farklı türdeki ortaöğretim kurumlarında çalışan matematik öğretmenlerinin yazılı sınavlarda sordukları soruları YBT' ye göre incelemişler ve soruların alt düzey zihinsel becerileri ölçtüğü sonucuna ulaşmışlardır. Ulaştıkları sonuç bu araştırmanın sonuçları ile tutarlıdır. Karaman ve Bindak (2017) ilköğretim matematik öğretmenlerinin sınav soruları ile TEOG matematik sorularının YBT'ye göre sınıflandırmışlar. Sonuç olarak bilgi boyutunda olgusal ve üst bilişsel bilgi türünü ölçen soru bulamamışlar ve soruların ağırlıklı olarak alt bilişsel düzeyde olduğunu belirlemişlerdir. Ulaştıkları sonuç bu araştırmanın sonuçları ile benzerdir. Biber ve Tuna (2017) yaptıkları araştırmada ortaokul 5., 6., 7. ve 8. sinıflarda okutulan matematik ders kitaplarında yer alan alıştırma sorularını YBT' ye göre bilişsel düzeylerini incelemişlerdir. Araştırmacılar soruların genellikle "Anlama" ve "Uygulama" seviyesinde olduğunu tespit etmiş, öğrencilerin öğrendikleri bilgileri yeni durumlara uyarlayabilecekleri, yorum yapabilecekleri üst bilişsel seviyeye uygun soruların az olduğunu vurgulamışlardır. Bu sonuçlar bu araştırmada ulaşılan sonuçlarla benzerdir. Sedef, Kul ve Çalık Uzun (2017) araştırmasında 2017 yılında güncellenmiş ortaokul matematik dersi öğretim programında yer alan kazanımların YBT'nin bilişsel ve bilgi düzeyine göre incelemesini yapmıştır. Yaptıkları analiz sonucunda; bilişsel süreç boyutu açısından kazanımların anlama ve uygulama basamaklarında, bilgi boyutu açısından ise kavramsal ve işlemsel bilgi basamaklarında yoğunlaştığını tespit etmiş̧ler. Ayrıca kazanımları sınıf seviyesi göre değerlendirmişler, kazanımların bilişsel süreç boyutu açısından kısmen benzerlik gösterdiği; bilgi boyutu açısından da farklılık gösterdiği sonucuna ulaşmışlardır. Araştırmanın bu sonuçları bu araştırmada ele alınan soruların bilişsel ve bilgi boyutu açısından dağılımı ile benzerlik gösterse de sınıf düzeyi açısından oluşan farklılığın anlamlılığı bakımından benzer değildir. Aktan (2019) İlkokul Matematik Öğretim Programında yer alan kazanımların YBT 'ye göre sınıflandırmasını yapmayı amaçladığı araştırmada kazanımların alt düzey bilişsel basamakları içeren uygulama, anlama ve hatırlama gibi alt düzey basamaklarda yoğunlaştığı sonucuna ulaşmıştır. Bu sonuç yapılan bu araştırmanın sonuçlarıyla örtüşmektedir. Ulum ve Taşkaya (2019) yaptıkları çalışmada ilkokul 2, 3, ve 4. sınıf Türkçe ders ve çalışma kitaplarında yer alan etkinlikleri, YBT' ye göre sınıflayıp değerlendirmişlerdir. Araştırmanın sonuçlarından etkinliklerin üst düzey zihinsel becerilerden çok alt düzey zihinsel becerileri ölçtüğü sonucu bu araştırma ile tutarlı olsa da sınıf düzeyi bakımından üst düzey zihinsel beceriler ve alt düzey zihinsel becerileri ölçme potansiyeli anlamlı bir farklilık göstermediği sonucu bu araştırmanın sonuçlarının desteklememektedir. Şanlı (2019) yılında yaptığı çalışmada lise düzeyindeki coğrafya ders kitaplarında bulunan soruları YBT'ye göre incelemiş ve bilişsel düzeyde "kavrama ve hatırlama"; bilgi birikimi boyutunda ise "kavramsal bilgi ve olgusal bilgi" basamağında soruların yaygın kullanıldığı sonucuna ulaşmıştır. Farklı alanda ve düzeyde yapılmış bir çalışma olmasına rağmen araştırmanın sonuçları bu araştırma ile tutarlıdır. Lise düzeyine çıkılmasına karşın üst bilişsel bilgilerden veya üst düzey zihinsel becerilenden uzak sorular ders kitaplarında yer bulmuştur. Ulutaş ve Kara (2019) yaptıkları araştırmada Türkçenin yabancı dil olarak öğretiminde kullanılan ders kitaplarındaki okuduğunu anlama metin altı sorularını, YBT’ye göre sınıflandırmış ve soruların bilişsel süreç boyutunun 
temel düzeyinde (hatırlama, anlama, uygulama) yoğunlaştığı; üst düzey bilişsel becerileri (çözümleme, değerlendirme, yaratma) basamağında oldukça az soru olduğunu belirlenmiştir. Yine farklı alanda ve düzeyde yapılmış bir çalışma olmasına rağmen araştırmanın sonuçları bu araştırma ile tutarlıdır. Karakaş Yıldırım'ın (2020) 8. Sınıf Türkçe ders kitaplarındaki etkinliklerin YBT'ye göre sınıflandırılması üzerine yapılmış çalışmada ulaşılan sonuçlar etkinliklerin \%61'inin alt düzey, \%39'unun ise üst düzey becerilere yönelik olduğu sonucuyla bu araştırmanın sonuçlarıyla benzerdir.

Araştırmada ulaşılan sonuçlar doğrultusunda şu önerile getirilmiştir.

1. Matematik ders kitaplarının uluslararası hazırlanırken İMDÖP'ün vurguladığı üst bilişsel beceriler ile ilgili noktalar göz önünde tutulmalıdır.

2. Hazırlanan ders ve çalışma kitapları taslak haline geldikten sonra taksonominin bilgi birikimi ve bilişsel süreç boyutu temel alınarak dengeli bir dağılım açısından kontrol edilmelidir. Bunu yaparken bu konuda çalışan akademisyenlerin görüşü alınabilir.

3. Araştırma sonuçları öğretmenlere matematik ölçme ve değerlendirme sorularını düzenleme aşamasında kılavuz olabilir. Öğretmenler ders kitaplarının ölçme ve değerlendirme açısından eksik kalan noktalarını bu bağlamda giderebilir.

4. $\mathrm{Bu}$ araştırmada, yaygın olarak kullanıldığ 1 ifade edilen, ders ve çalışma kitaplarında bulunan içerik, bilgi birikimi ve bilişsel süreç boyutu açısından dengeli hale getirilirse, daha çok üst düzey becerileri ölçen uluslararası sınavlardan da (PISA ve TIMSS gibi) ülke olarak daha başarılı olunması sonucunu beklenebilir. Bunu değerlendiren boylamsal çalışmalar yapılabilir.

\section{Kaynaklar}

Aktan, O. (2019). İlkokul matematik öğretim programı dersi kazanımlarının yenilenen Bloom taksonomisine göre incelenmesi. Pamukkale Üniversitesi Ĕgitim Fakültesi Dergisi 48(1), 15-36. https://doi.org/10.9779/pauefd.523545.

Amer, A. (2006). Reflections on Bloom's revised taxonomy. Electronic Journal of Research in Educational Psychology, 4(1), 213-230.

Anderson, L. W. ve Krathwohl, D. R. (Eds.) (2001). A Taxonomy for learning teaching and assessing. a revision of Bloom's taxonomy of educational objectives. New York: Longman.

Anderson, L. W. ve Krathwohl, D. R. (Eds.) (2014). Öğrenme ögrretim ve değerlendirme ile ilgili bir sınıflama: Bloom'un eğitimin hedefleri ile ilgili sınıflamasının güncelleştirilmiş biçimi. (D. A. Özçelik, Çev.) (2. Baskı). Ankara: Pegem Akademi Yayıncılık. https://doi.org/10.16916/aded.93992.

Arı, A. (2011). Bloom'un gözden geçirilmiş bilişsel alan taksonomisinin Türkiye'de ve uluslararası alanda kabul görme durumu. Kuram ve Uygulamada Eğitim Bilimleri, 11(2), 749-772.

Arslan, S. ve Özpınar, İ. (2009). İlköğretim 6. sınıf matematik ders kitaplarının öğretmen görüşleri doğrultusunda değerlendirilmesi. Dicle Üniversitesi Ziya Gökalp Eğitim Fakültesi Dergisi, 12, 97-113. https://doi.org/10.17556/erziefd.463013.

Ayvacı, H. Ş. ve Türkdoğan, A. (2010). Yeniden yapılandırılan Bloom taksonomisine göre fen ve teknoloji dersi yazılı sorularının incelenmesi. Türk Fen Eğitimi Dergisi, 7(1), 13-25. https://doi.org/10.17121/ressjournal.302.

Bloom, B. S., Engelhart, M. D., Furst, E. J., Hill, W. H. ve Krathwohl, D. R. (1956). Taxonomy of educational objectives: The classification of educational goals. Handbook I: Cognitive Domain. B. S. Bloom (Yay. haz.). New York: McKay. https://doi.org $/ 10.1177 / 001316446502500324$.

Davidson, R. A. ve Baldwin, B. A. (2005). Cognitive skills objectives in intermediate accounting textbooks: Evidence from end-of-chapter material. Journal of Accounting Education, 23(2), 79-95. https://doi.org/10.1016/j.jaccedu.2005.05.001. 
Demirel, Ö. ve Kıroğlu, K. (2006). Konu alanı ders kitabı incelemesi (2. Baskı). Ankara: Pegem A Yayınc1l1k. https://doi.org/10.14527/9786050370058.

DW. (2020). Türkiye'de eğitim: Özel ile devlet arasında kalan veliler. 28 Haziran 2020, Erişim adresi: https://www.dw.com/tr/t\%C3\%BCrkiyede-e\%C4\%9Fitim-\%C3\%B6zel-iledevlet-aras\%C4\%B1nda-kalan-veliler/a-48745622

Ensar, F. (2002). İlköğretim 6. sinıf Türkçe ders kitaplarındaki metin altı soruları üzerine bir inceleme. Gazi Üniversitesi, Ankara. https://doi.org/10.17218/hititsosbil.280818.

Forehand, M. (2010). Bloom's taxonomy. emerging perspectives on learning, Teaching and Technology. 26 Haziran 2020, Erişim adresi: http://epltt.coe.uga.edu/index.php?title= Bloom's_Taxonomy.

Güneş, F. (2012). Öğrencilerin düşünme becerilerini geliştirme. Türklük Bilimi Araştırmaları, (32), 127-146.

Karakaş Yıldırım, Ö. (2020). 8. sınıf Türkçe ders kitabındaki yazma etkinliklerinin yenilenmiş Bloom taksonomisine göre incelenmesi. Ana Dili Eğitimi Dergisi, 8(2), 315-325. https://doi.org/10.16916/aded.675304.

Karaman, M. ve Bindak, R. (2017). İlköğretim matematik öğretmenlerinin sınav soruları ile TEOG matematik sorularının yenilenmiş Bloom taksonomisine göre analizi. Current Research In Education, 3(2), 51-65. https://doi.org/10.9779/pauefd.585602.

Kılıç A. ve Seven, S. (2006). Konu alanı ders kitabı incelemesi, (6. Baskı). Ankara: Pegem A Yayıncilik.

Köğce, D. ve Baki, A. (2009). Matematik öğretmenlerinin yazılı sınav soruları ile ÖSS sınavlarında sorulan matematik sorularının Bloom taksonomisine göre karşılaştırılması. Pamukkale Üniversitesi Ë̆itim Fakültesi Dergisi, 26(26), 70-80. https://doi.org/ 10.9779/pauefd.585602.

Krathwohl, D. R. (2002). A Revision of Bloom's taxonomy: An overview. Theory Into Practice, 41(4), 212-218. https://doi.org/10.1207/s15430421tip4104_2.

Mayer-Sommer, A. (1990). Substance and Strategy in the accounting curriculum. Issues in Accounting Education, 129-142.

MEB (2018). Matematik dersi öğretim programı (ilkokul ve ortaokul 1, 2, 3, 4, 5, 6, 7 ve 8. sinıflar). Ankara. 28 Haziran 2019, Erişim adresi: http://mufredat.meb.gov.tr/Dosyalar /201813017165445-MATEMATIK\%20ÖĞRETIM\%20PROGRAMI\%202018v.pdf. https://doi.org/10.23891/efdyyu.2017.44

Orwin, R. G. ve Vevea, J. L. (2009). Evaluating coding decisions. The handbook of research synthesis and meta-analysis, 2, 177-203.

Patten, R. ve Williams, D. (1990). There's trouble right here in our accounting programs: the challenge to accounting educators. Issues in Accounting Education, 175-179.

Patton, M. Q. (2014). Nitel araştırma ve değerlendirme yöntemleri (M. Bütün ve S. D. Beşir, Çev.) (3. Bask1). Ankara: Pegem Akademi.

Piaget, J. (1953). The origins of intelligence in children. Journal of Consulting Psychology, 17(6), 467-467.

Sedef, Ç., Kul, Ü. ve Çalık Uzun, S. (2018). Ortaokul matematik dersi öğretim programındaki kazanımların yenilenmiş Bloom taksonomisine göre incelenmesi. Abant İzzet Baysal Üniversitesi Eğitim Fakültesi Dergisi, 18(2), 775-795. https://doi.org/10.17240/ aibuefd.2018.18.37322-431437

Sprouse, R. (1989). The synergism of accountancy and accounting education. Accounting Horizons, 102-110.

Şanl, C. (2019). Investigation of question types in high school geography coursebooks and their analysis in accordance with the revised Bloom's taxonomy. Ege Coğrafya Dergisi, 28(2), 111-127.

Tuna, A. ve Biber, A. (2017). Ortaokul matematik kitaplarındaki öğrenme alanları ve Bloom taksonomisine göre karşılaştırmalı analizi. Ondokuz Mayıs Üniversitesi Eğitim Fakültesi Dergisi, 36(1), 161-174. https://doi.org/10.17556/erziefd.482751 
Ulum, H. ve Taşkaya, S. M. (2019). İlkokul 2, 3 ve 4. sınıf Türkçe ders ve çalışma kitaplarında yer alan etkinliklerin yenilenmiş Bloom taksonomisine göre incelenmesi. Kastamonu Ĕ̈itim Dergisi, 27(1), 107-118. https://doi.org/10.24106/kefdergi.2380

Ulutaş, M. ve Kara, M. (2019). Yabancı dil olarak Türkçe öğretimi ders kitaplarındaki metin altı sorularının yenilenmiş Bloom Taksonomisi'ne göre incelenmesi. Uluslararası Türkçe Edebiyat Kültür Eğitim (TEKE) Dergisi, 8(4), 2198-2214. https://doi.org/10.7884 /teke.4585.

Williams, D. (1991). The challenge of change in accounting education. Issues in Accounting Education, 126-133.

Wyatt, A. (1989). Interface between teaching/research and teaching/practice. Accounting Horizons, 125-128.

Yıldırım, A. ve Şimşek, H. (2013). Sosyal bilimlerde nitel araştırma yöntemleri (9. Baskı). Ankara: Seçkin Yayıncılık.

\section{Extended Abstract}

\section{Introduction}

Textbooks and workbooks are the mirrors of the curriculum. It is among the largest educational tools in terms of scope. They undertake important tasks in terms of fulfilling the measurement and evaluation function of the program. Textbooks and workbooks are important for determining whether the activities used in the educational process serve the purpose, to receive feedback and to make decisions. Textbooks and workbooks, which are the most easily accessible tools for the target audience, also help to reinforce the subject. In this context, an important educational tool, such as textbooks and workbooks, needs to be well analyzed both in terms of measuring highlevel mental skills and in terms of suitability of the student's mental level. Scientists have developed different taxonomies to establish and evaluate targets in the cognitive field. These taxonomies guide the creation of questions according to the objectives. Taxonomies serve as a system for question formation. In this system, teachers can organize facts and terms quickly and practically. Since taxonomies contain more concrete expressions of behaviour, they facilitate our work in adjusting, measuring and monitoring student behaviour. This research aims to classify the unit evaluation questions in primary school 1st, 2nd, 3rd and 4th-grade mathematics course and workbooks in terms of knowledge accumulation dimension and cognitive process dimension using the Revised Bloom Taxonomy. It is also to determine whether these activities have the potential to contribute to the development of high-level cognitive skills and whether they can contain information appropriate to the student's cognitive development.

\section{Method}

In the research, document review was used from the patterns of the qualitative research model. With this pattern, it is aimed to reach the data by examining the documents that are the source of the research and reflecting the research subject. The data of the study was gathered from the 444 unit evaluation questions in the Mathematics course books used at the 1st, 2nd, 3rd, and 4th classes of state primary schools in 2017-2018 education year. Two key tables were used to correctly and correctly place unit assessment questions in the YBT Specification Table. The first key table was prepared by the researchers. With this table, it is aimed to place the unit evaluation questions correctly and easily on the information dimension steps in the YBT Specification Table. With the second key table, it is aimed to correctly and easily place the unit evaluation questions in the cognitive skill dimension steps in the YBT Table of Specifications. In data analysis, descriptive analysis was used. The themes in which the data collected within the scope of the research were grouped were determined as the knowledge accumulation dimension and cognitive process dimension categories in the YBT. The themes to be grouped in this way are tabulated with frequency. 


\section{Result and Discussion}

Results of the study; questions are distributed in various ratios to the steps other than meta cognitive information. All of the 1st and 2nd-grade questions measure low-level cognitive skills. The majority of questions 3 and 4 measure lower-level cognitive skills. It gives a meaningful relationship between levels of cognitive process dimension and levels of textbooks.

"Unit evaluation questions in 1st, 2nd, 3rd and 4th-grade MDÇK are distributed in different ratios to the steps other than meta cognitive knowledge (factual knowledge, conceptual knowledge, procedural knowledge)". In this context, it is desirable not to include questions in the meta cognitive knowledge group which is completely abstract in primary schools.

Another result of the study is that there is a relationship between the levels (grade) of the unit evaluation questions and the cognitive process dimension levels (lower-level mental skills or higher-level mental skills) of YBT. As the grade level of the unit evaluation questions in the MDÇK taught in primary schools increases, so does the cognitive level (from lower to higher).

In line with the results obtained in the research, the following proposal was proposed. Although the studies in the literature show similarities with the results of this research, they differ in terms of the level of the books (primary, secondary, high school), the actuality of taxonomy (original, renovated), the area of the textbooks (Turkish, Social Studies, etc.). In the field of mathematics, no study classifies the unit evaluation questions in primary school level books according to YBT.

1. Considering the principles of international preparation of mathematics textbooks (eg. NCTM), textbooks and workbooks that meet the needs of society and the age should be prepared.

2. Unit evaluation questions in primary school mathematics textbooks can be examined by considering alternative approaches to YBT and different theoretical foundations (Gardner's Five Mind Model, etc.).

3. The results of the research can guide teachers in the process of organizing mathematical measurement and evaluation questions. Teachers can correct the missing points of textbooks in terms of measurement and evaluation in this context.

Ek 1. Etkinliklerin Bilgi Boyutu Basamaklarına Göre Sınıflama Tablosunda Gösterilmesinde Yararlanılan Anahtar Tablo.

\begin{tabular}{|c|c|}
\hline ANA GRUPLAR & ÖRNEKLER \\
\hline \multicolumn{2}{|l|}{ A.OLGUSAL BİLGİ } \\
\hline $\begin{array}{l}\text { Bir konunun kapsamını tanıyabilen bir } \\
\text { öğrencinin konu ile ilgili problemleri } \\
\text { çözebilmesi için bilmesi gerekli temel } \\
\text { bilgiler. }\end{array}$ & $\begin{array}{l}\text { Üçgen, kare, çember, prizma, piramit, koni gibi } \\
\text { matematiksel nesneleri ayırt etme, türev, limit, } \\
\text { integral, karekök gibi matematiksel sembolleri } \\
\text { bilme }\end{array}$ \\
\hline \multicolumn{2}{|l|}{ B.KAVRAMSAL BİLGİ } \\
\hline $\begin{array}{l}\text { Kapsamlı ve karmaşık bir olgunun } \\
\text { temel parçaları arasında var olan ve } \\
\text { olguyu oluşturan parçaları eşgüdümlü } \\
\text { hareket ettiren bütün bağlardır. }\end{array}$ & $\begin{array}{l}\text { Ondalık gösterimi verilen bir sayıyı (1,8 gibi) sayı } \\
\text { doğrusu üzerinde gösterme, düzgün çokgen örneği } \\
\text { verme ve çizme, aritmetik ve geometrik dizi için } \\
\text { örnek verme }\end{array}$ \\
\hline \multicolumn{2}{|l|}{ C.İSLEMSEL BİLGİ } \\
\hline $\begin{array}{l}\text { Bir şeyin nasıl yapılacağına dair } \\
\text { bilgidir. Problemlerin çözümünde } \\
\text { izlenecek yol, yöntem ve tekniklerden } \\
\text { nasıl yararlanacağ } 1 \text { bilinir. }\end{array}$ & $\begin{array}{l}\text { Tamsayı, kesir, cebirsel ifadelerde dört işlem } \\
\text { bilgisi, bir fonksiyonun tersini alma, üstel biçimde } \\
\text { verilen bir fonksiyonu logaritmik dönüşümünü } \\
\text { yapma, limit, türev ve integral alma }\end{array}$ \\
\hline \multicolumn{2}{|l|}{ D.ÜSTBİLIŞ BİLGİSİ } \\
\hline $\begin{array}{l}\text { Genel olarak bilişle alakalı bilgi, } \\
\text { bireyin kendi bilişinden haberdar ve } \\
\text { bilişiyle ilgili bilgi sahibi olması }\end{array}$ & $\begin{array}{l}\text { En çok beğenilen örüntü ya da süsleme modelinin } \\
\text { seçilmesi, en iyi öğrenilen konunun/kavramın ifade } \\
\text { edilmesi, en uygun çözüm yolunun ya da stratejinin } \\
\text { seçilmesi }\end{array}$ \\
\hline
\end{tabular}

